\title{
Impact of Crude Oil on Yield and Phytochemical Composition of Selected Green Leafy Vegetables
}

Johnson Odukoya ${ }^{\mathrm{a}, \mathrm{b}}$, Ronnie Lambert ${ }^{\mathrm{a}}$, and Ruben Sakrabani ${ }^{\mathrm{a}}$

${ }^{a}$ School of Energy, Environment and Agrifood, Cranfield University, Vincent Building 52(a), Cranfield University, Bedfordshire, MK43 0AL, United Kingdom

${ }^{\mathrm{b}}$ Chemistry Department, The Federal University of Technology, PMB 704 Akure, Ondo State, Nigeria

Address correspondence to: Ruben Sakrabani at School of Energy, Environment and Agrifood, Cranfield University, Vincent Building 52(a), Cranfield University, Bedfordshire, MK43 0AL, United Kingdom. E-mail: r.sakrabani@cranfield.ac.uk

\begin{abstract}
Total petroleum hydrocarbons (TPH) clean-up standards, intervention and/or target values, are designed to effectively manage introduction of toxic petroleum hydrocarbons into the environment. This research assessed the impact of some crude oil remediation intervention values, involving sub-lethal concentrations of crude oil, on yield and phytochemical contents of kale (Brassica oleracea L.) and lettuce (Lactuca sativa L.). Crude oil contamination within the range examined did not affect emergence; yield and phytochemical distributions were affected at some levels of contamination, particularly $10,000 \mathrm{mg} \cdot \mathrm{kg}^{-1} \mathrm{TPH}$. There is the potential of TPH to moderate effects of crude oil at $10,000 \mathrm{mg} \cdot \mathrm{kg}^{-1}$ to enhance contents of some phenolics and organic
\end{abstract}


acids in green leafy vegetables, but it causes accelerated maturity and leaf senescence. Use of crude oil remediation intervention values below $10,000 \mathrm{mg} \cdot \mathrm{kg}^{-1} \mathrm{TPH}$ appears to be effective.

Keywords: crop yield, intervention value, organic acids, petroleum hydrocarbons, phenolics

Spillage of crude oil, as a result of exploration and production, occurs leading to introduction of petroleum hydrocarbons $(\mathrm{PH})$ into the environment, which have been identified as one of the most common environmental contaminants (Adati, 2012; Mehboob et al., 2009; Wang et al., 2012). Among deleterious effects, plant growth may be affected for some time after the initial contamination (Plice, 1948; De Jong, 1980).

To reduce the impact of $\mathrm{PH}$ on the environment, various remediation approaches have been adopted and remediation standards established (Soesilo and Wilson, 1997; Ebuehi et al., 2005). Total petroleum hydrocarbons (TPH) clean-up standards, intervention and/or target values, are described by several national regulations (Anonymous, 2011; Pinedo et al., 2014; Wayne and James, 1999). Intervention values are those where PH concentrations in the environment presents serious risk to the general ecosystem in which higher concentration beyond the intervention value denotes serious contamination (Anonymous, 2011).

The effect of $\mathrm{PH}$ at crude oil remediation intervention values (CRIV) on agrifood production is poorly understood. Cramer et al. (2011) noted that abiotic factors, like crude oil/PH contamination (Nie et al., 2010), in the environment affects optimal plant growth and yield. These abiotic challenges have been linked to reduction in agrifood production and influence nutritional value/quality of vegetables (Kumar et al., 2014). 
Studies on effects of crude oil/PH on plants (Inckot et al., 2011; Adieze et al., 2012; Baruah et al., 2014), have mostly considered the impact on plant growth/yield while Chupakhina and Maslennikov (2004), Noori et al. (2012) and Baruah et al. (2014) considered the impact on a few crop quality parameters. Most of these studies recorded reduced shoot biomass with increasing concentration of crude oil. However, shoot heights and weights were improved in 2 species at $1 \%$ w/w oil-in-soil (Adieze et al., 2012). Other reports indicated there were other responses due to presence of oil in soil. Soil containing 5-10\% crude oil enhanced accumulation of anthocyanins, ascorbic acid and riboflavin in 25-day-old seedlings (Chupakhina and Maslennikov, 2004). Crude oil contamination led to increase in total flavonoids and total phenolics in mycorrhizal plants (Noori et al., 2012). Meanwhile, chlorophyll content decreased with increasing concentration of crude oil (Baruah et al., 2014). The presence of crude oil and the level at which it causes damage to plants needs clarification.

This study was undertaken to evaluate the impact of fresh crude oil contamination, and the impact of $\mathrm{PH}$, on crop yield and distribution of phytochemicals in two green leafy vegetables (GLV).

\section{Materials and methods}

The experiment was conducted at Cranfield University research glasshouse with an average temperature of $24^{\circ} \mathrm{C}$ and $58.2 \%$ relative humidity. The growing medium, John Innes No. 2 compost (Hurstridge, Surrey, UK), which contained sufficient nutrition to support the crops over the term of the experiment, was used. Seeds of kale, Brassica oleracea (L.), cv. Starbor F1 Hybrid, and Butterhead lettuce, Lactuca sativa (L.), cv. Analena, were from Thompson and Morgan (Suffolk, UK). The crude oil used had 10 of the United States Environmental Protection Agency 
priority polycyclic aromatic hydrocarbons and higher concentration of lighter alkane fractions. Other details on the chemical composition of the crude oil are as reported by Odukoya and Lambert (2015).

Treatments of TPH: 0 (control), 1,500, 3,000, 5,000 or $10,000 \mathrm{mg} \cdot \mathrm{kg}^{-1}$ were imposed on plants in $16 \mathrm{~cm}$ dia pots (Plastecnic Perego SPA, Perego, Italy) using a randomized complete block design. After thorough mixing of the John Innes No. 2 compost and crude oil, pots were irrigated to ensure all treatments had the same moisture content at the start of the experiment. Moisture was sustained at $50 \%$ field capacity throughout the experiment by addition of appropriate volumes of water as required by each pot based on the TPH treatments. Seed dormancy was broken before planting by prior soaking in distilled water (Oyedeji et al., 2012). Ten seeds were randomly selected and sown; 3 replicates of each treatment, with the appropriate concentration of crude oil (except the control). To ensure changes in yield and phytochemical composition of plants were solely because of $\mathrm{PH}$, no fertilizer and pesticides were applied. Thinning to 1 plant per pot was carried out $10 \mathrm{~d}$ after planting.

Before thinning, the procedure of Faluyi (1986) was followed for determination of emergence percent (E \%). At the end of the experiment, 60 days after sowing, above-ground plant fresh weight and the fresh root weights were recorded. Harvested vegetables were immediately processed and prepared for further analyses after thorough washing and freeze-drying. Samples were ground into powder using a blender and kept at $-40^{\circ} \mathrm{C}$ prior to chemical analyses.

As GLV are known to contain high concentrations of ascorbic acid with distinct color, flavor, and medicinal activity (Gupta et al., 2005), effect of TPH treatments on phytochemical contents of the GLV was investigated. 
The Howard Davies method was used to extract total phenolics in above-ground plant parts. An ethanol:water mix (80:20 v:v, $3 \mathrm{~mL})$ was added to powdered samples $(150 \mathrm{mg})$ in a 7 $\mathrm{mL}$ vial. After mixing, samples in vials were placed in a shaking water bath at $70^{\circ} \mathrm{C}$ for $2 \mathrm{~h}$ and removed every $30 \mathrm{~min}$ for $20 \mathrm{~s}$ vortexing. Samples were air cooled and passed through a Cronus $25 \mathrm{~mm}$ PTFE $0.2 \mu \mathrm{m}$ syringe filter (SMI-LabHut Ltd., Gloucestershire, UK). Two hundred fifty $\mathrm{mg} \cdot \mathrm{mL}^{-1}$ of sodium carbonate (Fisher Scientific, Leicestershire, UK) was prepared using $100 \%$ deionized water with stirring and then gravity filtration through Whatman 1 qualitative filter paper. The calibration standard of $5.0 \mathrm{mg} \cdot \mathrm{mL}^{-1}$ gallic acid (Sigma-Aldrich, St Louis, MO, USA) was prepared using ethanol:water $(10: 90 \mathrm{v}: \mathrm{v})$ from which calibration standards of: $0.05,0.10,0.15$, 0.25 and $0.50 \mathrm{mg} \cdot \mathrm{mL}^{-1}$ were prepared.

For quantification of total phenolics, $20 \mu \mathrm{L}$ of the gallic acid standard, or sample filtrate, was placed in a cuvette with addition of $3.2 \mathrm{~mL}$ of deionized water, $200 \mu \mathrm{L}$ of Folin and Ciocalteu's phenol reagent (Fisher Scientific, Loughborough, UK) and $600 \mu \mathrm{L}$ of the previously prepared sodium carbonate solution. A $20 \mu \mathrm{L}$ of the sample blank was similarly treated. All samples were mixed in the cuvette and left in the dark for $2 \mathrm{~h}$ at room temperature for color to develop. Absorbance was measured at $765 \mathrm{~nm}$ with a Helios Gamma UV/Visible spectrophotometer (Unicam Limited, Cambridge, UK). The concentration of total phenolics in samples was calibrated against gallic acid.

The Howard Davies method was used to extract total flavonoids in powdered samples (150 $\mathrm{mg}$ ). Forty $\mathrm{mg} \cdot \mathrm{mL}^{-1}$ of sodium hydroxide (Fisher Scientific, Fair Lawn, NJ, USA) was prepared using a solvent mix of ethanol:water (50:50 v:v) with mixing. The calibration standard of quercetin (Sigma-Aldrich, Saint Louis, MO, USA) was prepared within the range of 1.0 and $0.005 \mathrm{mg} \cdot \mathrm{mL}^{-}$ 1. For quantification of total flavonoids in samples, $100 \mu \mathrm{L}$ of quercetin standard, or sample filtrate, 
was measured in a cuvette after addition of $3 \mathrm{~mL}$ of sodium hydroxide solution. Samples were mixed in the cuvette, left for $10 \mathrm{~min}$ at room temperature for color development and absorbance measured at $420 \mathrm{~nm}$ using a spectrophotometer. The sample blank $(100 \mu \mathrm{L})$, substituted for the quercetin standard, or sample filtrate, was also used. Calibration against quercetin standards was carried out to determine total flavonoid concentration in above-ground plant parts.

The modified method of Terry et al. (2007) was used in extraction and quantification of organic acids in above-ground parts of leafy vegetables. Three-hundred mg of individual freezedried powdered sample was weighed into a $7 \mathrm{~mL}$ vial and $3 \mathrm{~mL}$ of HPLC grade water added. The slurry was allowed to stand at room temperature for 5 min followed by vortexing for $30 \mathrm{~s}$. To ensure ease of filtration, samples were centrifuged at 3,202 $\times \mathrm{g}$ for $10 \mathrm{~min}$ at $4^{\circ} \mathrm{C}$. Following this, samples were passed through a Cronus $25 \mathrm{~mm}$ PTFE $0.2 \mu \mathrm{m}$ syringe filter. The vegetable extract obtained $(20 \mu \mathrm{L})$ was injected into an Alltima HP C18 AQ $5 \mu$ (Grace Davison, Deerfield, IL) 250 $\mathrm{mm} \times 4.6 \mathrm{~mm}$ (Serial number: 614110890 and Part number: 87820) column with an OPTIGUARD® $1 \mathrm{~mm}$ guard column. Analytical grade $25 \mathrm{mM} \mathrm{KH}_{2} \mathrm{PO}_{4}$ (Fisher Scientific, Loughborough, UK) in HPLC grade water was used as the mobile phase adjusted to $\mathrm{pH} 2.5$ using phosphoric acid (Acrōs Organics, Fair Lawn, NJ, USA). Separation was achieved with an HPLC system (1200 series, Agilent Technologies, Waldbronn, Germany) at isocratic conditions for 10 min at a flow rate of $1.5 \mathrm{~mL} \cdot \mathrm{min}^{-1}$ and column temperature of $35^{\circ} \mathrm{C}$. At a wavelength of $210 \mathrm{~nm}$, eluted organic acids were detected with a photodiode array detector (DAD Serial No. DE60556253, Agilent Technologies, Waldbronn, Germany).

The desired non-volatile organic acids concentrations in sample extracts were quantified against calibration standards of citric acid (Fisher Scientific, Fair Lawn, NJ, USA), L-ascorbic acid (vitamin C) and L (-) malic acid (Sigma-Aldrich, Saint Louis, MO, USA) within the range of 0.025 
and $1.0 \mathrm{mg} \cdot \mathrm{mL}^{-1}$ by comparing peak areas using ChemStation (rev.B.04.01, Agilent Technologies) software. The $0.025 \mathrm{mg} \cdot \mathrm{mL}^{-1}$ standard was used to determine Limit of Detection (LOD) and Limit of Quantitation (LOQ) set at 3 and 10 times the signal/noise ratio, respectively (Liguori et al., 2006; Odukoya and Lambert, 2015).

The modified Mackinney (1941), Arnon (1949), and Ghani (2011) methods were used to quantify chlorophyll a, chlorophyll $b$ and total carotenoid contents of GLV in semi-darkness. For this determination, $200 \mathrm{mg}$ of ground samples were extracted with $3 \mathrm{~mL}$ of acetone (Fisher Scientific, Fair Lawn, NJ, USA):HPLC grade water (80:20 v:v) solvent mix with agitation for 2 min at room temperature. Thereafter, $4 \mathrm{~mL}$ of extraction solvent mix was added followed by vortexing for 2 min before gravity filtration. Equations of Wellburn (1994) for spectrophotometers with a resolution range of 1-4 $\mathrm{nm}$ were used for determination of chlorophyll a $\left(\mathrm{Chl}_{\mathrm{a}}\right)$, chlorophyll $\mathrm{b}\left(\mathrm{Chl}_{\mathrm{b}}\right)$ and total carotenoids $\left(\mathrm{C}_{\mathrm{x}+\mathrm{c}}\right)$ contents of extracts using an $10 \mathrm{~mm}$ LP optical glass sample cell (HACH company, Loveland, CO, USA) according to manufacture instructions.

Effects of TPH on yield and phytochemical compositions of GLV were evaluated. Two way analysis of variance (SPSS, ver. 22.0, IBM Statistics for Windows, IBM Corp., Armonk, NY) was used to assess interactions. If interactions were significant, they were used to explain results. If interactions were not significant, means were separated with Tukey's test.

\section{Results and discussion}

Except for citric acid distribution in vegetable samples, all traits and tested parameters were affected by variety, crude oil treatment, and the interaction (Table 1). Crude oil contamination in the range 1,500 to $10,000 \mathrm{mg} \cdot \mathrm{kg}^{-1} \mathrm{TPH}$ had no effect on vegetable emergence, mean values of 86 and $88 \%$ for B. oleracea and L. sativa, respectively. This is associated with TPH concentration 
lower than phytotoxic level and kind of petroleum used (Inckot et al., 2011), and agrees with Tang et al. (2011) where 1.5\% TPH was the critical value for animal and phytotoxicity; this is higher that the range of crude oil concentrations used in this study.

Contaminants in the environment can impact shoot growth (Oyedeji et al., 2013), and responses of above-ground plant yield of the leafy vegetables utilized in this work indicated some intervention values used in national regulations would affect plant yield. Compared with controls, crude oil contamination at CRIV from 5,000 to $10,000 \mathrm{mg} \cdot \mathrm{kg}^{-1} \mathrm{TPH}$ reduced above-ground plant yield of B. oleracea (Figure 1). Above-ground plant yield of L. sativa was more sensitive to increase in crude oil as reduced yield of samples from the 3,000 to $10,000 \mathrm{mg} \cdot \mathrm{kg}^{-1} \mathrm{TPH}$ treatments occurred. The $10,000 \mathrm{mg} \cdot \mathrm{kg}^{-1} \mathrm{TPH}$ treatment produced the least above-ground plant yield. Poor development of shoots can be employed by plant to reduce rate of water use and delay onset of a more severe condition (Acosta-Gallegos and Shibata, 1989).

Root yields of B. oleracea and L. sativa, compared with the control, were affected by crude oil contamination with the $10,000 \mathrm{mg} \cdot \mathrm{kg}^{-1} \mathrm{TPH}$ causing the least root yield (Figure 2). Generally, and in agreement with Jarrell and Beverly (1981), reduced yield (a function of dry matter accumulation) of these plants at some specific CRIV indicates: (i) blockage of metabolic pathway by toxic concentrations of crude oil components, (ii) decline in photosynthesis, (iii) poor photosynthate translocation, (iv) water limiting-lowered turgor pressure, (v) hormonal imbalance, and (vi) accelerated senescence.

The only effect of crude oil contamination on total phenolics and total flavonoid contents of the leafy vegetables was at $10,000 \mathrm{mg} \cdot \mathrm{kg}^{-1} \mathrm{TPH}$ which increased total phenolics and total flavonoids contents of L. sativa samples (Figure 3, 4). The highest level of total phenolics and total flavonoids in L. sativa indicated crude oil contamination at this CRIV, and its induced nutrient 
deficiency in the growing media, enhanced flavonoid (a type of stress-induced phenylpropanoids) levels in the samples. These flavonoids are a form of phenylpropanoid compounds that biotic and abiotic challenges induce in plants (Dixon and Paiva, 1995).

Increased total phenolics and total flavonoids in L. sativa, due to treatment with 10,000 $\mathrm{mg} \cdot \mathrm{kg}^{-1} \mathrm{TPH}$, indicates it is a crude oil tolerant plant (Noori et al., 2012) as it was likely able to alter its metabolic processes which affect production of phenolics and flavonoids as well as reduce oxidative damage to its cells. Changes in this plant's phytochemicals' contents could be attributed to modification in gene expression of enzymes like phenylalanine ammonia-lyase (PAL) and chalcone synthase (CHS) indications of improved plant secondary metabolism to assist $L$. sativa in resisting pollution at this level of petroleum (Noori et al., 2012). The outcome of phytochemicals distribution in the L. sativa is consistent with Wang and Frei(2011) where it was determined that phenolic content increases when crops are under challenging conditions owing to stimulation of principal enzymes of the phenylpropanoid pathway.

Trace amounts of malic and citric acids are important organic acids in plants (Fennema et al., 1996) and L-ascorbic acid (vitamin C) is the most essential vitamin in vegetables in human diets (Lee and Kader, 2000). Crude oil levels from 3,000-10,000 mg $\mathrm{kg}^{-1} \mathrm{TPH}$ enhanced malic acid concentration in L. sativa (Figure 5). The CRIV at 3,000 or 5,000 $\mathrm{mg} \cdot \mathrm{kg}^{-1} \mathrm{TPH}$ reduced ascorbic acid content of B. oleracea (Figure 6) compared to the $10,000 \mathrm{mg} \cdot \mathrm{kg}^{-1} \mathrm{TPH}$ treatment. Ascorbic acid content of the L. sativa due to treatment with 5,000 and $10,000 \mathrm{mg} \cdot \mathrm{kg}^{-1} \mathrm{TPH}$ were reduced compared to the control (Figure 6). Crude oil contamination increased citric acid content in $B$. oleracea due to treatment with the 5,000 and $10,000 \mathrm{mg} \cdot \mathrm{kg}^{-1} \mathrm{TPH}$ while the lowest citric acid content for L. sativa was from the $10,000 \mathrm{mg} \cdot \mathrm{kg}^{-1} \mathrm{TPH}$ treatment (Figure 7). Alterations in citric acid and malic acid concentration of B. oleracea and L. sativa at specific CRIV indicate that plants 
respond differently to presence of $\mathrm{PH}$. These changes suggest possible major interconversions between citric acid and malic acid (Ergle and Eaton, 1949).

Effects of $\mathrm{PH}$ on organic acids distribution in plants have been associated with decrease in ascorbic acid content due to PH level (Nwaogu and Ujowundu, 2010; Nwazue, 2011). Reduction in ascorbic acid at some CRIV affirms the exposure of GLV to abiotic challenge (Gaur and Sharma, 2014) arising from PH contamination and results from the antioxidant/free radical scavenging ability of ascorbic acid in neutralizing reactive oxygen species and free radicals which reduces its concentration.

CRIV from 1,500-10,000 $\mathrm{mg} \cdot \mathrm{kg}^{-1} \mathrm{TPH}$ did not affect malic acid/citric acid ratios in $B$. oleracea. The CRIV of 5,000 or $10,000 \mathrm{mg} \cdot \mathrm{kg}^{-1} \mathrm{TPH}$ increased malic acid/citric acid ratio in $L$. sativa compared with the control (Figure 8). The higher malic acid/citric acid ratios at these CRIV levels indicate increased maturity (Meredith et al., 1989) of harvested L. sativa which stimulates the process of senescence involving natural aging of organs or termination of plant life (Chen and Dong, 2016).

Responses to crude oil pollution and nutrient availability can affect chlorophyll content in leaves (Baruah et al., 2014); the influence of crude oil contamination below the phytotoxic level on chlorophyll content is yet to be clarified. Crude oil at CRIV of $10,000 \mathrm{mg} \cdot \mathrm{kg}^{-1} \mathrm{TPH}$ resulted in increased chlorophyll b content (Figure 10) as well as chlorophyll a and b (Figure 9, 10) contents of B. oleracea and L. sativa samples, respectively.

Assessment of chlorophyll $\mathrm{a}$ and $\mathrm{b}$ contents of the GLV supports Gross (1991) who reported that chlorophyll $\mathrm{a}$ is the major pigment in higher plants. However, the increase in chlorophyll contents at crude oil contamination level of $10,000 \mathrm{mg} \cdot \mathrm{kg}^{-1} \mathrm{TPH}$ contradicts others (Achuba, 2006; Ibemesim, 2010; Al-Hawas et al., 2012; Baruah et al., 2014) in which 
environmental contamination was associated with reduced chlorophyll content. The $B$. oleracea and L. sativa had increased chlorophyll despite the increased $\mathrm{PH}$ level indicating they are more tolerant to PH than plants used in previous studies.

Total carotenoids contents in B. oleracea and L. sativa were reduced at $10,000 \mathrm{mg} \cdot \mathrm{kg}^{-1}$ TPH compared with the control (Figure 11). This agrees with Gross (1991), that environmental factors, as was from crude oil contamination, affect carotenoid distribution in plants.

The only difference in the $B$. oleracea $\mathrm{Chl} \mathrm{a/b}$ ratio was between the $10,000 \mathrm{mg} \cdot \mathrm{kg}^{-1} \mathrm{TPH}$ and the 1,500 to $5,000 \mathrm{mg} \cdot \mathrm{kg}^{-1} \mathrm{TPH}$ treatments (Figure 12). Crude oil contamination at 10,000 $\mathrm{mg} \cdot \mathrm{kg}^{-1} \mathrm{TPH}$ reduced the $\mathrm{Chl} \mathrm{a} / \mathrm{b}$ ratio in L. sativa compared with other treatments. The difference in growing conditions (Lefsrud et al., 2007) arising from crude oil contamination resulted in alteration of pigment ratios of $B$. oleracea and $L$. sativa samples. The $\mathrm{Chl} \mathrm{a} / \mathrm{b}$ ratio in $L$. sativa treated with $10,000 \mathrm{mg} \cdot \mathrm{kg}^{-1} \mathrm{TPH}$ was lower than the control (Figure 12) indicating accelerated leaf senescence (Gross, 1991) at this remediation intervention value.

Plant yield, which is specie-dependent, may be affected by some intervention values used in national regulations while high level of $\mathrm{PH}$ may enhance concentrations of some phytochemicals in GLV owing to the negative impact of crude oil on soil conditions (Chupakhina and Maslennikov, 2004). It appears L. sativa, within the period of its life cycle, can tolerate PH when grown in low crude oil contaminated sites at a concentration below the phytotoxic level. The plant may, however, still experience reduced yield and accelerated leaf senescence. To ensure minimal negative impact of crude oil contamination on crop yield and quality, use of CRIV at $\leq 5,000$ $\mathrm{mg} \cdot \mathrm{kg}^{-1} \mathrm{TPH}$ is encouraged.

\section{Acknowledgement}


The work was supported by the Petroleum Technology Development Fund (PTDF), Nigeria, [PTDF/E/OSS/PHD/OJO/625/12].

\section{References}

Achuba, F. 2006. The effect of sublethal concentrations of crude oil on the growth and metabolism of cowpea (Vigna unguiculata) seedlings. Environmentalist 26:17-20. (doi: 10.1007/ s10669-006-5354-2).

Acosta Gallegos, J.A. and J. K. Shibata. 1989. Effect of water stress on growth and yield of indeterminate dry-bean (Phaseolus vulgaris) cultivars. Field Crop Research 20:81-93. (doi: 10.1016/0378-4290(89)90054-3).

Adati, A.K. 2012. Oil exploration and spillage in the Niger Delta of Nigeria. Civil and Environmental Research 2:38-51.

Adieze, I.E., J.C Orji, R.N. Nwabueze, and G.O.C. Onyeze. 2012. Hydrocarbon stress response of four tropical plants in weathered crude oil contaminated soil in microcosms. International Journal of Environmental Studies 69(3):490-500. (doi: 10.1080/00207233.2012.665785).

Al-Hawas, G.H.S., W.M. Shukry, M.M. Azzoz, and R.M.S. Al-Moaik. 2012. The effect of sublethal concentrations of crude oil on the metabolism of Jojoba (Simmodsia chinensis) seedlings. International Research Journal Plant Science 3(4):54-62.

Anonymous. 2011. Environmental assessment of Ogoniland. United Nations Environment Programme, Nairobi, Kenya.

Arnon, D.I. 1949. Copper enzymes in isolated chloroplasts. Polyphenoloxidase in Beta vulgaris. Plant Physiology 24(1):1-15. 
Baruah, P., R.R. Saikia, P.P. Baruah, and S. Deka. 2014. Effect of crude oil contamination on the chlorophyll content and morpho-anatomy of Cyperus brevifolius (Rottb.) Hassk. Environmental Science and Pollution Research 21:12530-12538. (doi: 10.1007/s11356014-3195-y)

Chen, Y. and Dong, H. 2016. Mechanisms and regulation of senescence and maturity performance in cotton. Field Crops Research. (doi: 10.1016/j.fcr.2016.02.003).

Chupakhina, G.N. and P.V. Maslennikov. 2004. Plant adaptation to oil stress. Russian Journal of Ecology 35(5):290-295. (doi:10.1023/B:RUSE.0000040681.75339.59).

Cramer, G.R., K. Urano, S. Delrot, M. Pezzotti, and K. Shinozaki. 2011. Effects of abiotic stress on plants: a systems biology perspective. BioMed Central Plant Biology 11(163):1-14.

De Jong, E. 1980. The effect of a crude oil spill on cereals. Environmental Pollution (Series A) 22(3):187-196.

Dixon, R.A. and N.L. Paiva. 1995. Stress-induced phenylpropanoid metabolism. The Plant Cell 7:1085-1097.

Ebuehi, O., I. Abibo, P. Shekwolo, K. Sigismund, A. Adoki, and I. Okoro. 2005. Remediation of crude oil contaminated soil by enhanced natural attenuation technique. Journal of Applied Sciences and Environmental Management 9(1):103-106.

Ergle, D.R. and Eaton, F.M. 1949. Organic acids of the cotton plant. Plant Physiology 24(3):373388.

Faluyi, M.A. 1986. Investigations on seedling vigour in cashew (Anacardium occidentale L.), Plant Breeding 97:237-245.

Fennema, O.R., M. Karel, S.W. Sanderson, S.R. Tannenbaum, and J.R. Whitaker. 1996. Food Chemistry, 3rd ed., Marcel Dekker, New York. 
Gaur, R.K. and P. Sharma. 2014. Approaches to plant stress and their management. Springer India, New Delhi.

Ghani, A. 2011. Effect of chromium toxicity on growth, chlorophyll and some mineral nutrients of Brassica juncea L. Egyptian Academic Journal of Biological Sciences 2(1):9-15.

Gross, J. 1991. Pigments in vegetables: Chlorophylls and carotenoids. Springer Science+Business Media, New York.

Gupta, S., A.J. Lakshmi, M.N. Manjunath, and J. Prakash. 2005. Analysis of nutrient and antinutrient content of underutilized green leafy vegetables. Food Science and Technology 28:339-345. (doi: 10.1016/j.1wt.2004.06.012).

Ibemesim, R.I. 2010. Effect of salinity and Wytch farm crude oil on Paspalum conjugatum Bergius (Sour grass). Journal of Biological Sciences 10(2):122-130.

Inckot, R.C., G.D.O. Santos, L.A. de Souza, and C. Bona. 2011. Germination and development of Mimosa pilulifera in petroleum-contaminated soil and bioremediated soil. Flora 206:261266. (doi: 10.1016/j.flora.2010.09.005).

Jarrell, W.M. and R.B. Beverly. 1981. The dilution effect in plant nutrition studies, pp. 197-224. In: N.C. Brady (ed.). Advances in Agronomy, Academic Press, New York.

Kumar, S.P., P.S. Minhas, V. Govindasamy, and R.L. Choudhary. 2014. Influence of moisture stress on growth, development, physiological process and quality of fruits and vegetables and its management strategies, pp. 125-148. In: R.K. Sharma (ed.). Approaches to plant stress and their management, Springer, New Delhi, India.

Lee, S.K. and A.A. Kader. 2000. Preharvest and postharvest factors influencing vitamin C content of horticultural crops. Postharvest Biology and Technology 20(3):207-220. [doi: 10.1016/S0925-5214(00)00133-2]. 
Lefsrud, M., D. Kopsell, A. Wenzel, and J. Sheehan. 2007. Changes in kale (Brassica oleracea L. var. acephala) carotenoid and chlorophyll pigment concentrations during leaf ontogeny. Scientia Horticulturae 112 (2):136-141. (doi: 10.1016/j.scienta.2006.12.026).

Liguori, L., K. Heggstad, H. T. Hove, and K. Julshamn. 2006. An automated extraction approach for isolation of 24 polyaromatic hydrocarbons (PAHs) from various marine matrixes. Analytica Chimica Acta 573:181-188. (doi: 10.1016/j.aca.2006.01.082).

Mackinney, G. 1941. Absorption of light by chlorophyll solutions. The Journal of Biological Chemistry 140 (2):315-322.

Mehboob, F., H. Junca, G. Schraa, and A.J.M. Stams. 2009. Growth of Pseudomonas chloritidismutans $\mathrm{AW}-1^{\mathrm{T}}$ on $n$-alkanes with chlorate as electron acceptor. Applied Microbiology and Biotechnology 83(4):739-747. (doi: 10.1007/s00253-009-1985-9).

Meredith, F.I., J.A. Robertson, and R.J. Horvat. 1989. Changes in physical and chemical parameters associated with quality and postharvest ripening of harvester peaches. Journal of Agricultural and Food Chemistry 37:1210-1214. (doi: 10.1021/jf00089a002).

Nie, M., N. Xian, X. Fu, X. Chen, and B. Li. 2010. The interactive effects of petroleumhydrocarbon spillage and plant rhizosphere on concentrations and distribution of heavy metals in sediments in the Yellow River Delta, China. Journal of Hazardous Materials 174(1):156-161. (doi: 10.1016/j.jhazmat.2009.09.030).

Noori, A.S., H.Z. Maivan, and E. Alaie. 2012. Changes in total phenol and flavonoid contents in Chrysanthemum leucanthemum under crude oil contamination. Advances in Environmental Biology 6(12):3057-3064.

Nwaogu, L.A. and C.O. Ujowundu. 2010. Effect of petroleum hydrocarbon pollution on the nutritional value of ripe guava (Psidium guajava) fruits grown in Imo State, Nigeria. 
International Journal of Biological and Chemical Sciences 4(2):450-455. (doi: 10.4314/ijbcs.v4i2.58152).

Nwazue, N.R. 2011. The effect of crude oil spill on the ascorbic acid content of some selected vegetable species: Spinacea oleraceae, Solanum melongena and Talinum triangulare in an oil polluted soil. Pakistan Journal of Nutrition 10(3):274-281. (doi: 10.3923/pjn. 2011.274.281)

Odukoya, J. and R. Lambert. 2015. Remediation by Enhanced Natural Attenuation (RENA): A beneficial strategy for polyaromatic hydrocarbon degradation and agrifood production, Proceedings World Congress on New Technologies, 15-17 July 2015, Alimara Hotel, Barcelona, Spain.

Oyedeji, A., A. Adebiyi, M. Omotoyinbo, and C. Ogunkunle. 2012. Effect of crude oilcontaminated soil on germination and growth performance of Abelmoschus esculentus L. Moench - A widely cultivated vegetable crop in Nigeria. American Journal of Plant Sciences 3(10):1451-1454. (doi: 10.4236/ajps.2012.310174).

Oyedeji, S., I.O. Raimi, and A.I. Odiwe. 2013. A comparative assessment of the crude oilremediating potential of Cynodon dactylon and Eleusine indica. Environmental and Experimental Biology 11:145-150.

Pinedo, J., R. Ibáñez, J.P. Lijzen, and A. Irabien. 2014. Human risk assessment of contaminated soils by oil products: Total TPH content versus fraction approach. Human and Ecological Risk Assessment 20(5):1231-1248. (doi: 10.1080/10807039.2013.831264).

Plice, M.J. 1948. Some effects of crude petroleum on soil fertility. Soil Science Society Proceedings 13:413-416. 
Soesilo, J.A. and S.R. Wilson. 1997. Site remediation: Planning and management. CRC Press, Boca Raton, FL.

Tang, J., M. Wang, F. Wang, Q. Sun, and Q. Zhou. 2011. Eco-toxicity of petroleum hydrocarbon contaminated soil. Journal of Environmental Sciences 23(5):845-851. (doi: 10.1016/ S1001-0742(10)60517-7).

Terry, L.A., G.A. Chope, and J.G. Bordonaba. 2007. Effect of water deficit irrigation and inoculation with Botrytis cinerea on strawberry (Fragaria $\times$ ananassa) fruit quality. Journal of Agricultural and Food Chemistry 55(26):10812-10819. (doi: 10.1021/ jf072101n).

Wang, Y. and M. Frei. 2011. Stressed food - the impact of abiotic environmental stresses on crop quality. Agriculture, Ecosystems and Environment 141(3):271-286. (doi: 10.1016/j. agee.2011.03.017).

Wang, Z., C. Yang, Z. Yang, B. Hollebone, C. Brown, M. Landriault, J. Sun, S. Mudge, F. KellyHooper, and D. Dixon. 2012. Fingerprinting of petroleum hydrocarbons (PHC) and other biogenic organic compounds (BOC) in oil-contaminated and background soil samples. Journal of Environmental Monitoring 14(9):2367-2381. (doi: http://dx.doi. org/10. 1039/ 1039/c2em30339f).

Wayne, A.H. and S. James. 1999. Technical basis for current soil management levels of total petroleum hydrocarbons. 6th Annual International Petroleum Environmental Conference, 16-18 November 1999, Houston, TX.

Wellburn, A.R. 1994. The spectral determination of chlorophylls a and b, as well as total carotenoids, using various solvents with spectrophotometers of different resolution. Journal of Plant Physiology 144 (3):307-313. (doi: 10.1016/S0176-1617(11)81192-2). 
Table 1: Analysis of variance of measured variable as affected by vegetable variety and crude oil treatment.

\begin{tabular}{|c|c|c|c|c|c|c|c|c|c|c|c|c|c|}
\hline Source & $\mathrm{df}$ & $\begin{array}{c}\text { Shoot } \\
\text { weight }\end{array}$ & $\begin{array}{c}\text { Root } \\
\text { weight }\end{array}$ & TPC & TFC & $\begin{array}{c}\text { Malic } \\
\text { acid }\end{array}$ & $\begin{array}{c}\text { Ascorbic } \\
\text { acid }\end{array}$ & $\begin{array}{c}\text { Citric } \\
\text { acid }\end{array}$ & $\begin{array}{c}\mathrm{MA} / \mathrm{CA} \\
\text { ratio }\end{array}$ & Chl a & Chl b & TCC & $\begin{array}{c}\mathrm{Chl} \mathrm{a} / \mathrm{b} \\
\text { ratio }\end{array}$ \\
\hline $\mathrm{T} \times \mathrm{V}$ & 4 & $* *$ & $* *$ & $* *$ & $* *$ & $* *$ & $* *$ & $* *$ & $* *$ & $* *$ & $* *$ & $* *$ & $* *$ \\
\hline
\end{tabular}

$(\mathrm{CV})$

$\mathrm{ns}, * *$ not significant or significant at $\mathrm{p}<0.05$.

$\mathrm{TPC}=$ total phenolics content; $\mathrm{TFC}=$ total flavonoids content; $\mathrm{MA} / \mathrm{CA}$ ratio $=$ Malic acid/Citric acid ratio; $\mathrm{Chl} \mathrm{a}=\mathrm{Chlorophyll} \mathrm{a} ; \mathrm{Chl}$

$\mathrm{b}=$ Chlorophyll $\mathrm{b} ; \mathrm{TCC}=$ total carotenoids content; $\mathrm{Chl} \mathrm{a} / \mathrm{b}$ ratio $=$ Chlorophyll $\mathrm{a} / \mathrm{b}$ ratio 


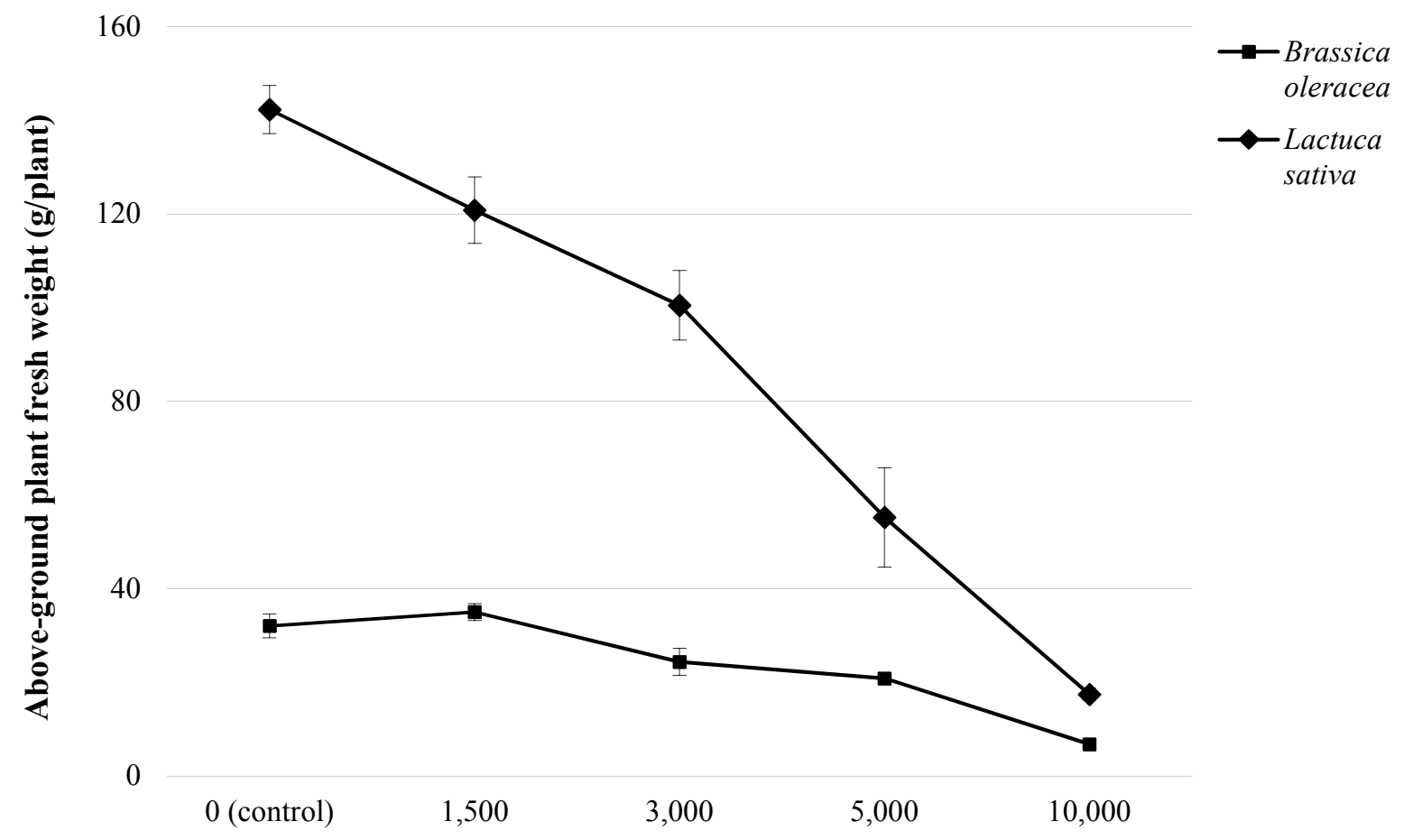

Crude oil treatment $\left(\mathrm{mg} \cdot \mathrm{kg}^{-1} \mathrm{TPH}\right)$

Figure 1. The interaction of crude oil contamination and vegetable species on above-ground plant fresh weight. In the interaction, values are means of 3 replicates with standard errors represented with bars. TPH $=$ total petroleum hydrocarbons. 


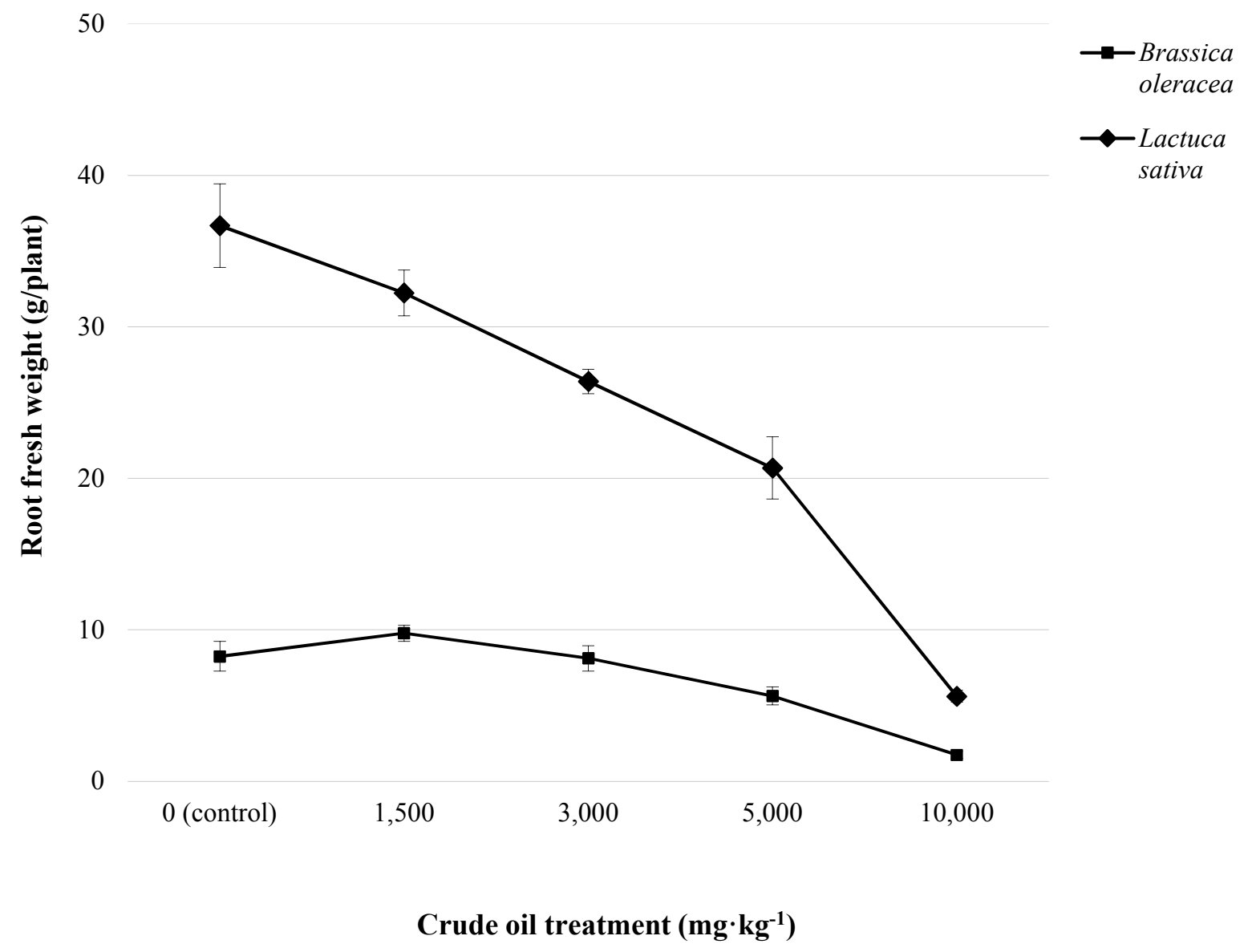

Figure 2. The interaction of crude oil contamination and vegetable species on root fresh weight. In the interaction, values are means of 3 replicates with standard errors represented with bars. TPH $=$ total petroleum hydrocarbons. 


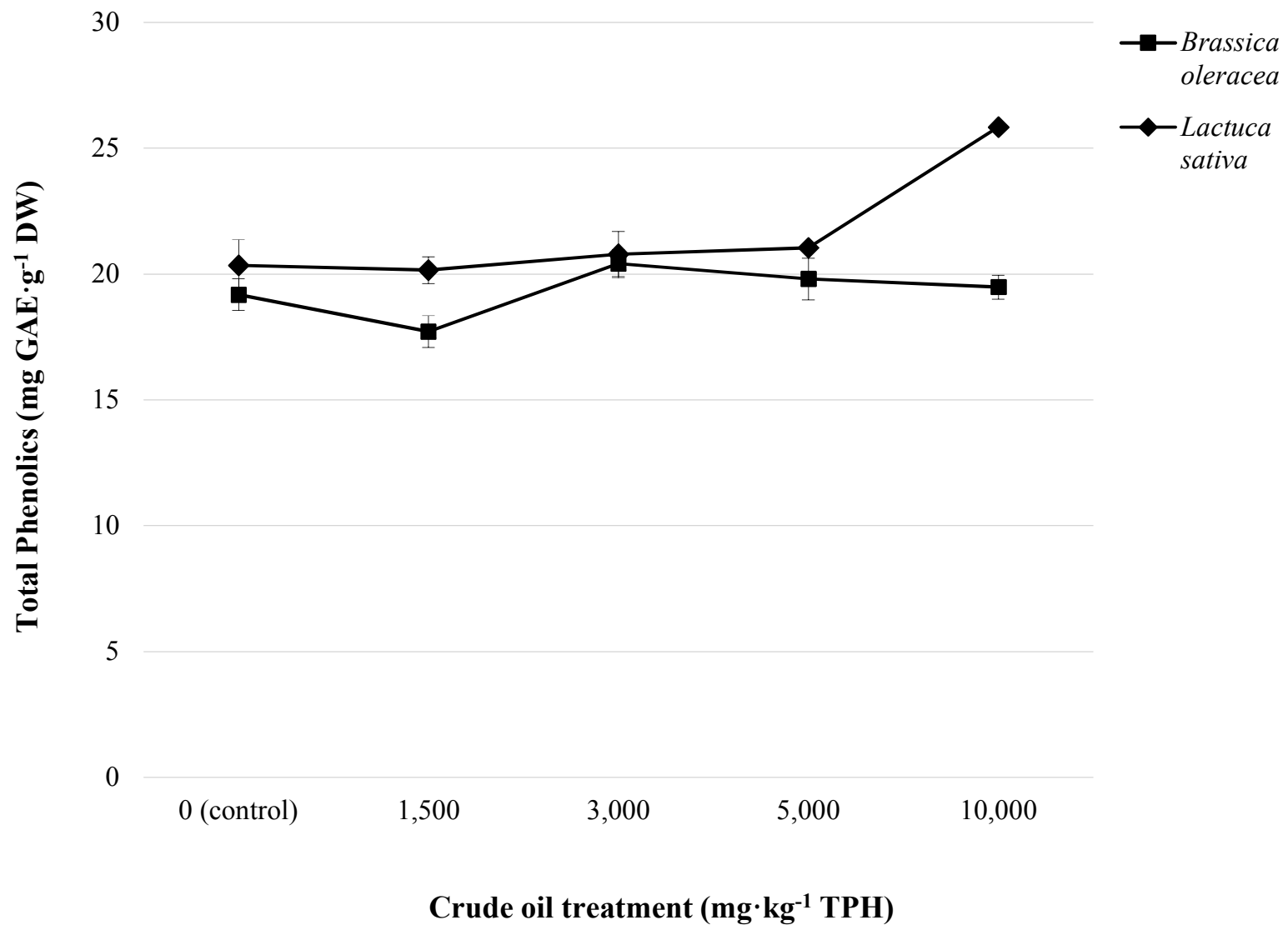

Figure 3. The interaction of crude oil contamination and vegetable species on total phenolics content. In the interaction, values are means of 3 replicates with standard errors represented with bars. $\mathrm{TPH}=$ total petroleum hydrocarbons. 


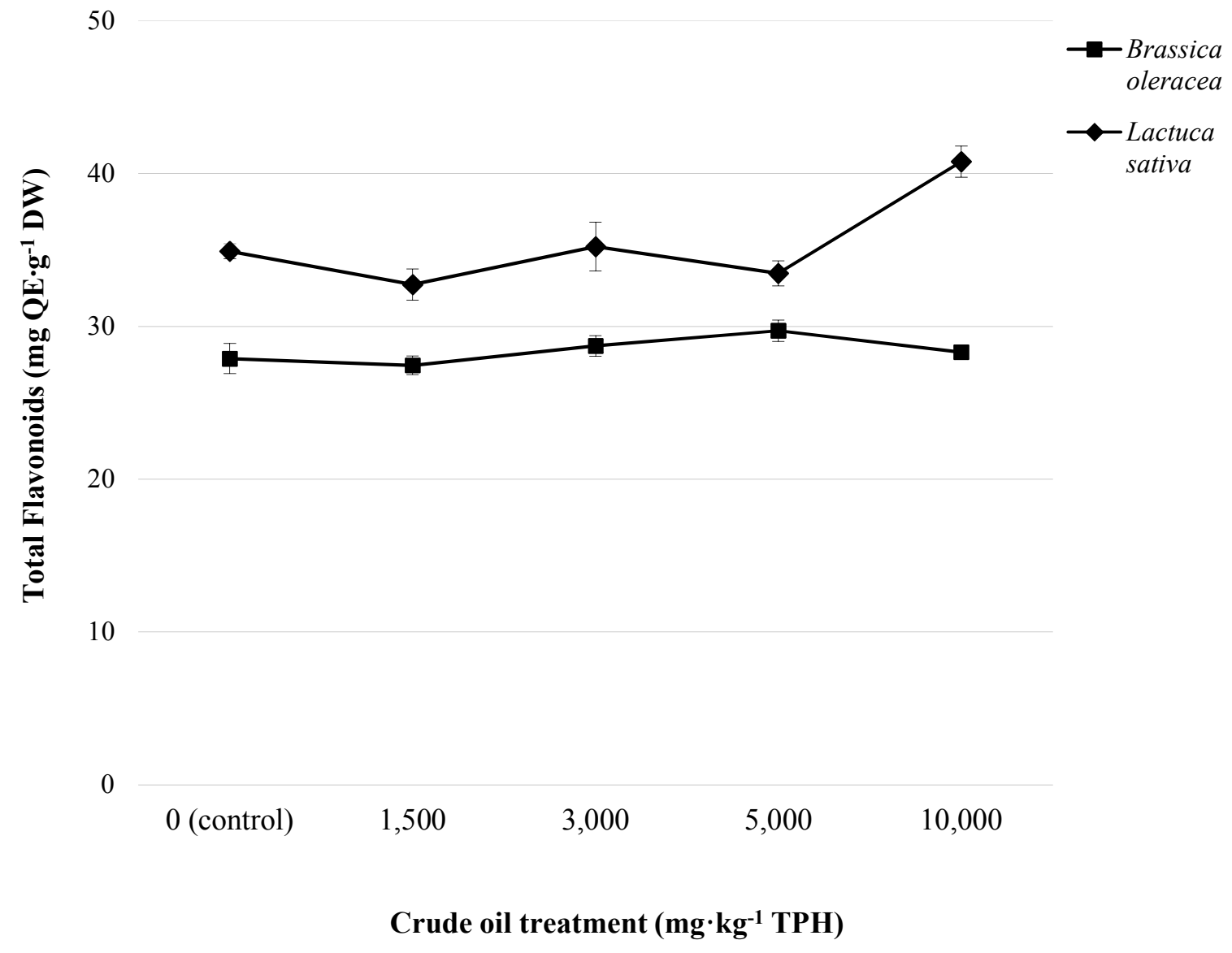

Figure 4. The interaction of crude oil contamination and vegetable species on total flavonoids content. In the interaction, values are means of 3 replicates with standard errors represented with bars. $\mathrm{TPH}=$ total petroleum hydrocarbons. 


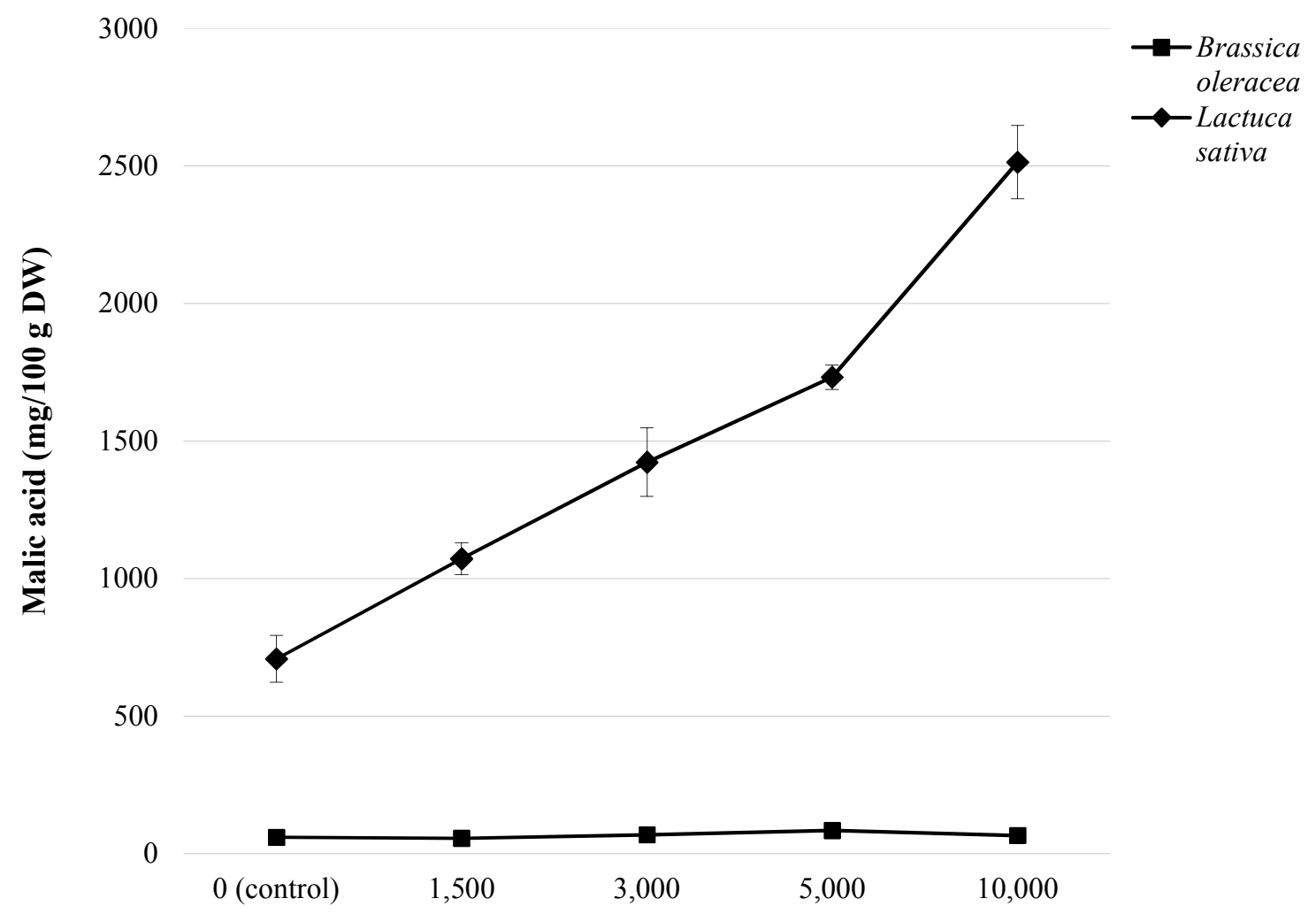

Crude oil treatment $\left(\mathrm{mg} \cdot \mathrm{kg}^{-1} \mathrm{TPH}\right)$

Figure 5. The interaction of crude oil contamination and vegetable species on malic acid content. In the interaction, values are means of 3 replicates with standard errors represented with bars. TPH $=$ total petroleum hydrocarbons. Error bars for the bottom line are included in the space taken by the symbols. 


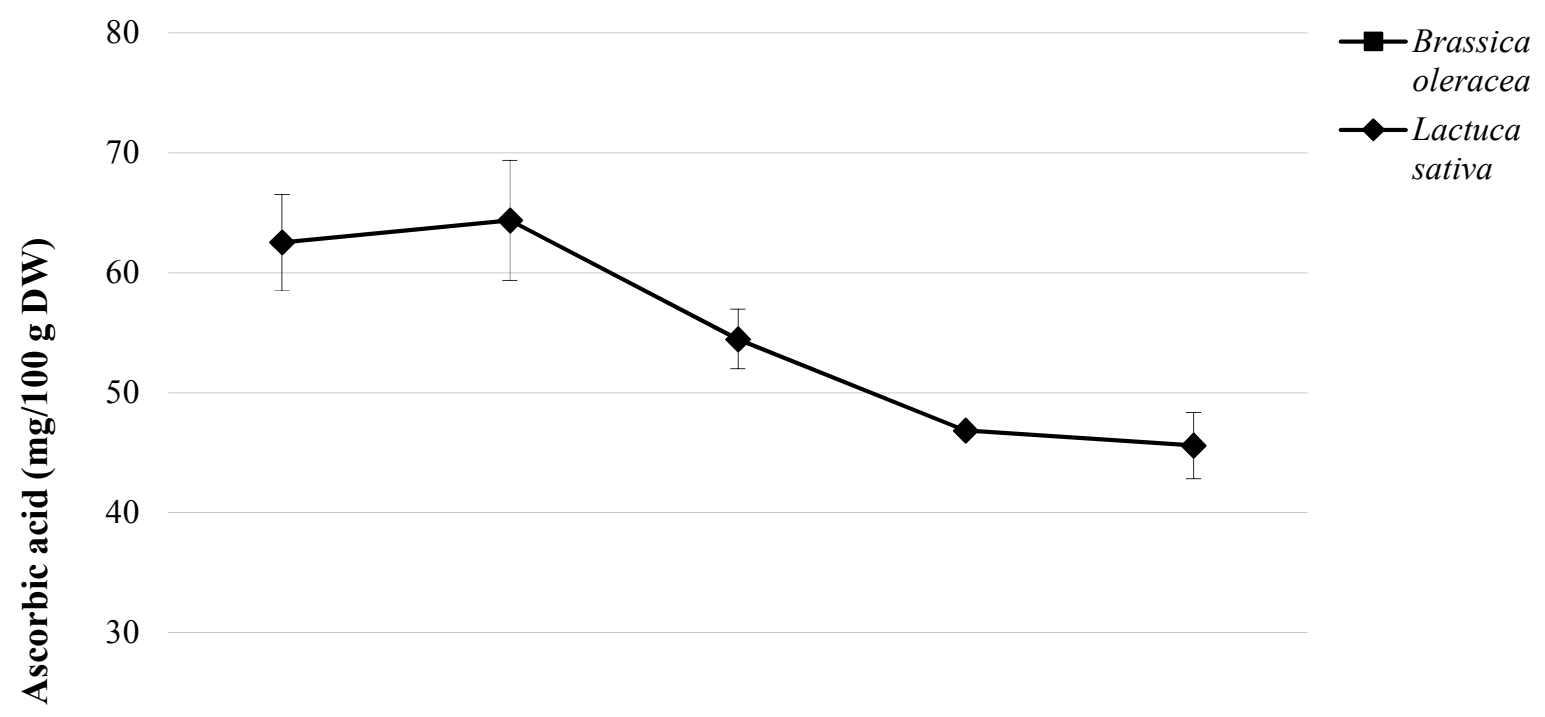

20

10

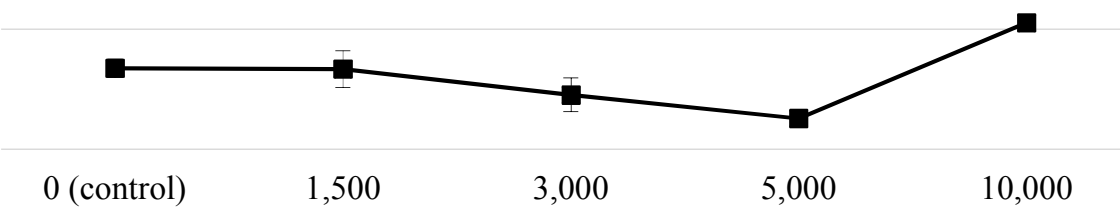

Crude oil treatment $\left(\mathrm{mg} \cdot \mathrm{kg}^{-1} \mathrm{TPH}\right)$

Figure 6. The interaction of crude oil contamination and vegetable species on ascorbic acid content. In the interaction, values are means of 3 replicates with standard errors represented with bars. $\mathrm{TPH}=$ total petroleum hydrocarbons. 


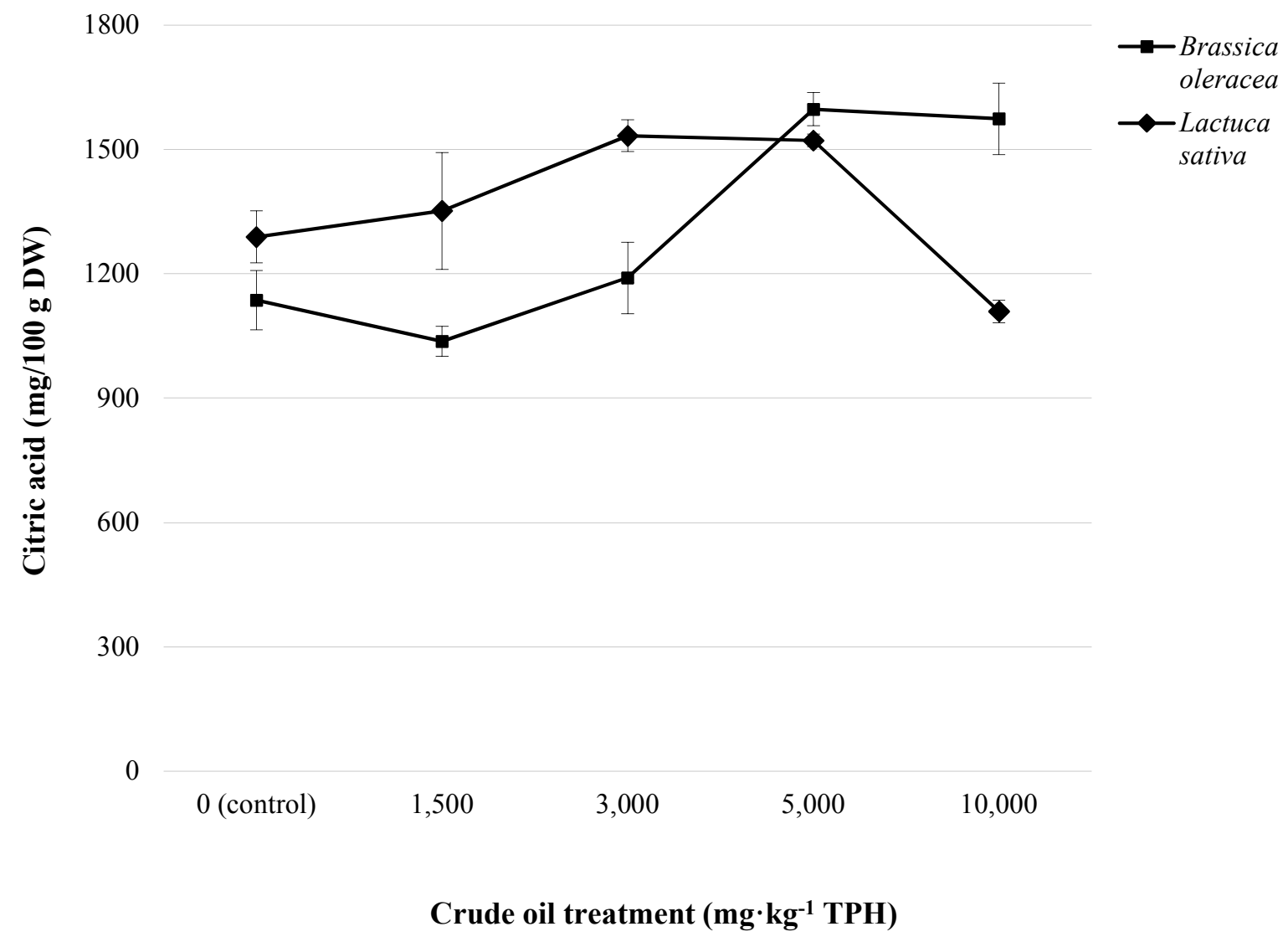

Figure 7. The interaction of crude oil contamination and vegetable species on citric acid content. In the interaction, values are means of 3 replicates with standard errors represented with bars. TPH $=$ total petroleum hydrocarbons. 


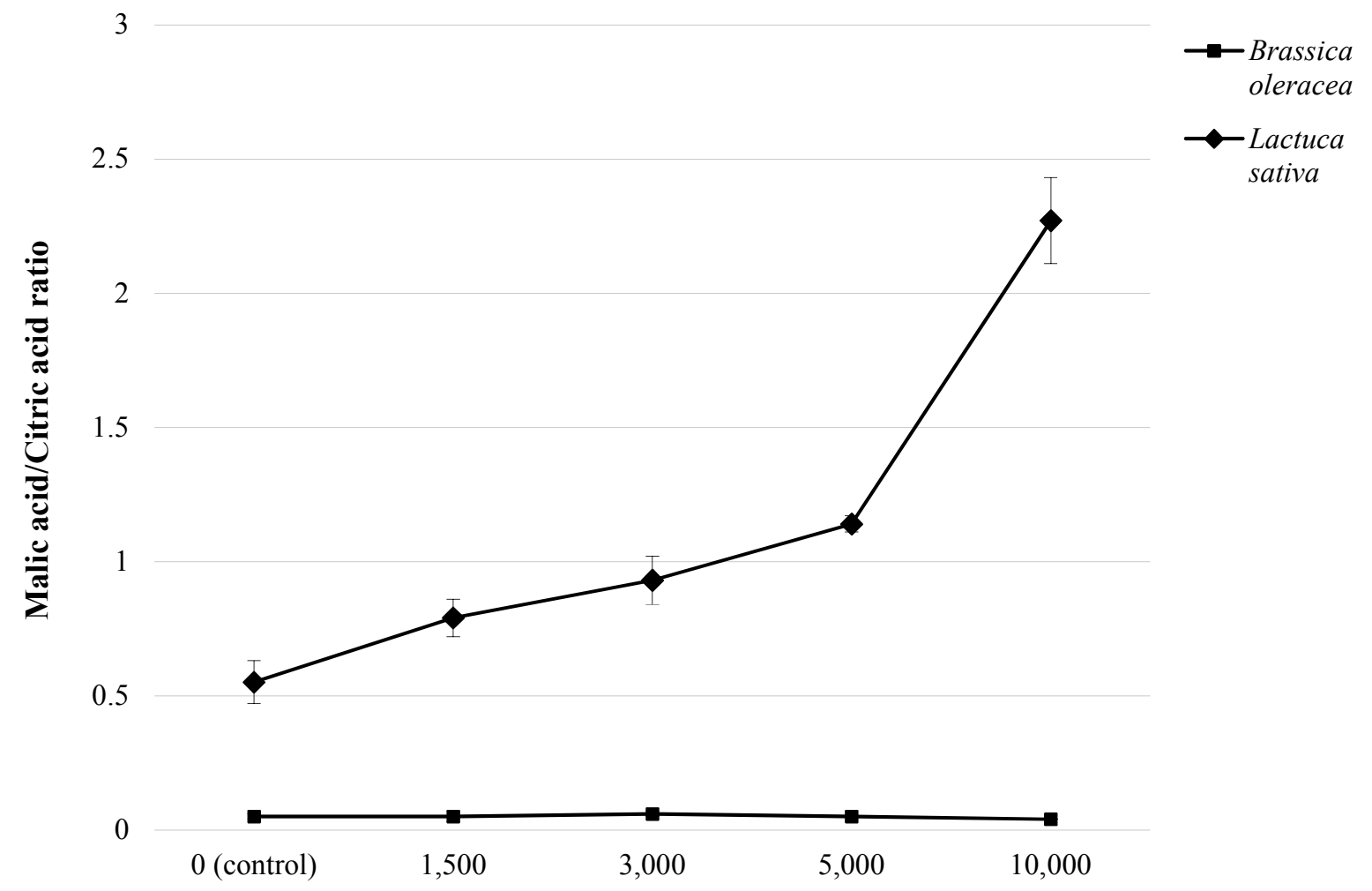

Crude oil treatment $\left(\mathrm{mg} \cdot \mathrm{kg}^{-1} \mathrm{TPH}\right)$

Figure 8. The interaction of crude oil contamination and vegetable species on malic acid/citric acid ratio. In the interaction, values are means of 3 replicates with standard errors represented with bars. $\mathrm{TPH}=$ total petroleum hydrocarbons. Error bars for the bottom line are included in the space taken by the symbols. 


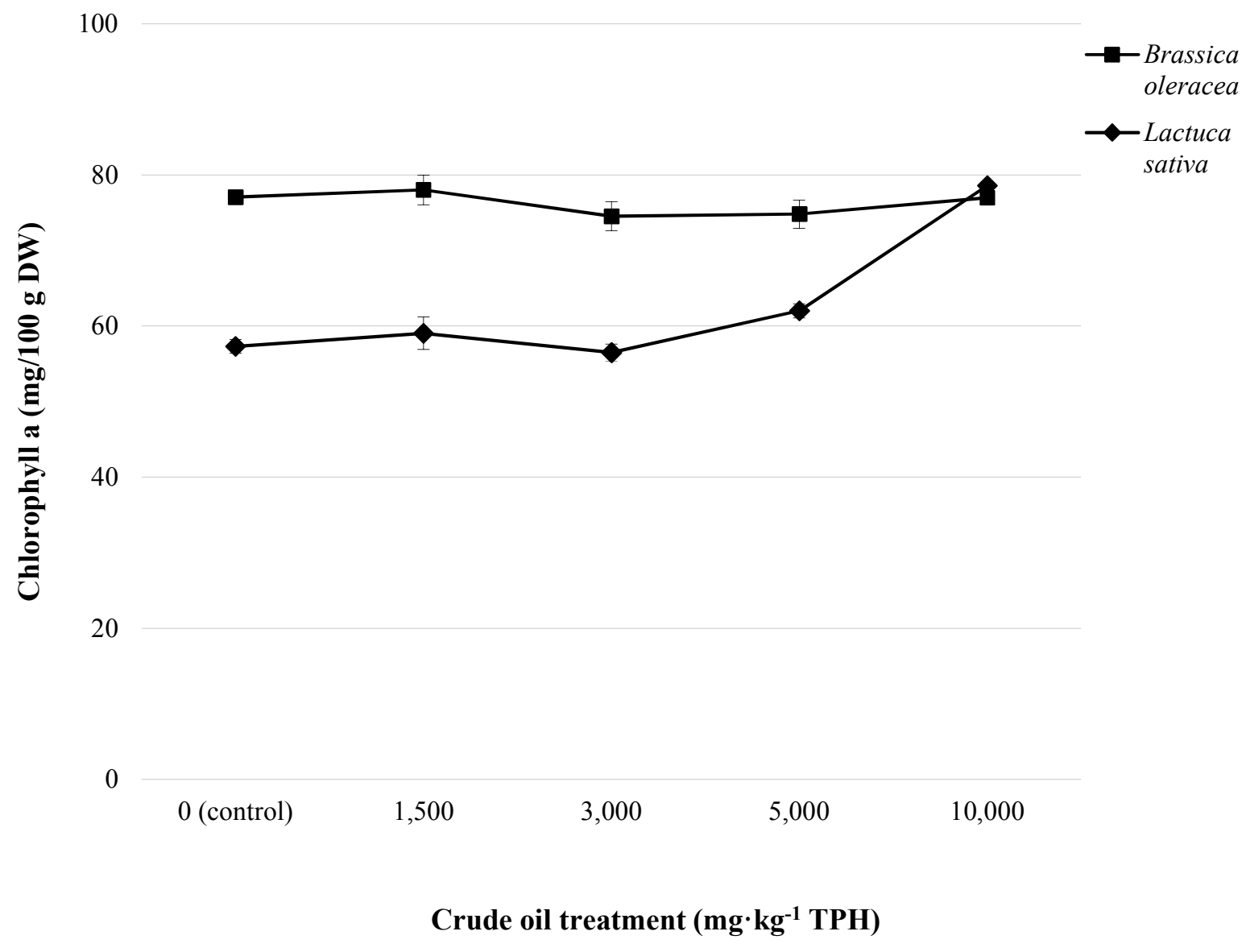

Figure 9. The interaction of crude oil contamination and vegetable species on chlorophyll a. In the interaction, values are means of 3 replicates with standard errors represented with bars. TPH $=$ total petroleum hydrocarbons. 


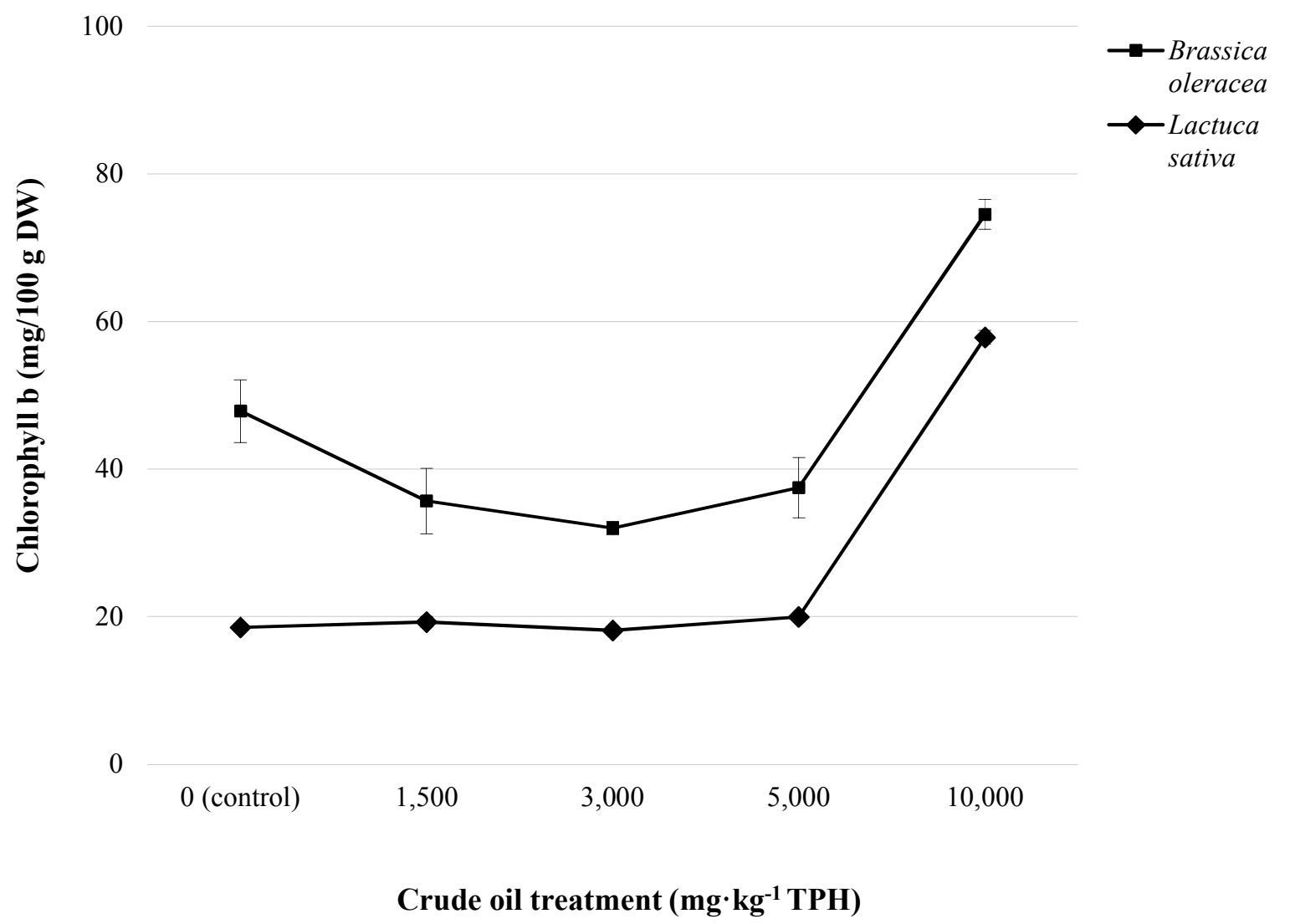

Figure 10. The interaction of crude oil contamination and vegetable species on chlorophyll b. In the interaction, values are means of 3 replicates with standard errors represented with bars. TPH $=$ total petroleum hydrocarbons. 


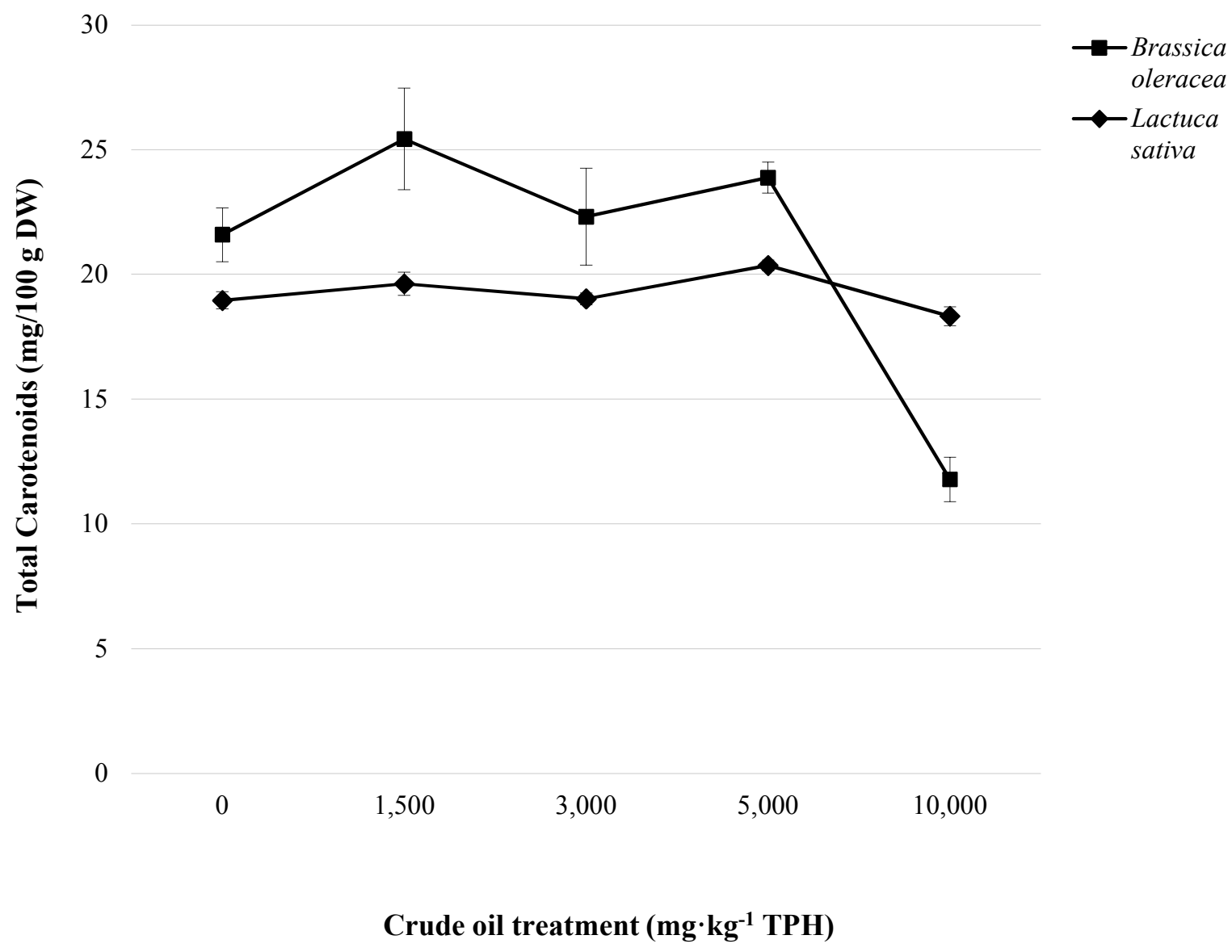

Figure 11. The interaction of crude oil contamination and vegetable species on total carotenoids content. In the interaction, values are means of 3 replicates with standard errors represented with bars. $\mathrm{TPH}=$ total petroleum hydrocarbons. 


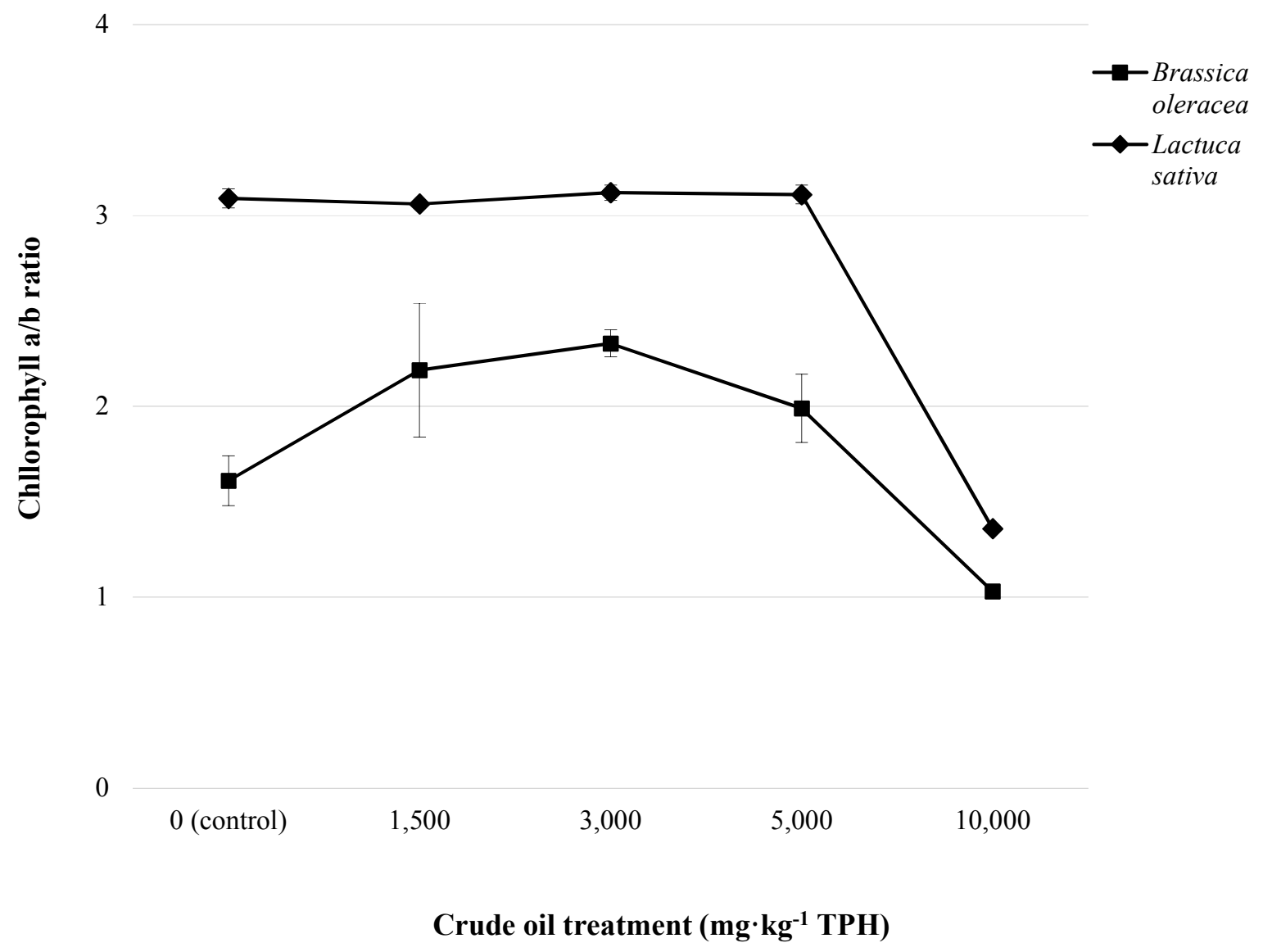

Figure 12. The interaction of crude oil contamination and vegetable species on chlorophyll $\mathrm{a} / \mathrm{b}$ ratio. In the interaction, values are means of 3 replicates with standard errors represented with bars. $\mathrm{TPH}=$ total petroleum hydrocarbons. 